- frequency of boar taint was high from the weight of $90 \mathrm{~kg}$ in Pietrain pigs (5I p. I0O of the judgements at cooking of cutlets) and from I Io $\mathrm{kg}$ in the Landrace breed (35 p. Ioo of opinions). These results confirm that frequency of boar taint varies according to breeds.

\title{
Heating fat to detect boar taint in boars, hogs and gilts from the Large White breed : olfactory assessment of each panel member according to fatty tissue
}

\author{
M. BONNEAU, L. TASSENCOURT* and B. DESMOULIN \\ Station de Recherches sur l'Élevage des Porcs, \\ *Laboratoire de Biométrie, I. N.R. A., C. N.R.Z., \\ 78350 Jouy en Josas
}

The odour of 3 fatty tissues from 88 Large White pigs (24 boars, 32 hogs and 32 gilts) was estimated at the slaughter-house by 5 male judges after quick heating with a soldering iron. The features of the judgements of each panel member were studied by multifactorial analysis, then the pigs were classed according to odour.

Main results about boars were the following :

- one of the panel members did not distinguish boar taint from other unpleasant odours and therefore he was eliminated. The other 4 panel members unequally distinguished these two kinds of odours according to fatty tissues ;

- few boars presented strong boar taint (o or I according to judges); however, slight taint was imputed to 33 or $46 \mathrm{p}$. Ioo of them. The odour of 20 to $4^{6} \mathrm{p}$. I oo of the boars remained undetermined because of the contradiction between the various judgements of the 3 fatty tissues of the same carcass by one judge ;

- fatty acid composition was not closely related to boar taint in fatty tissues.

Slight boar taint was imputed to o 4-14 p. Ioo of hogs and gilts. Moreover, frequency of unpleasant odours was as high in hogs and gilts as in boars.

\section{Production of heavy carcasses from primiparous or nulliparous gilts}

\author{
C. LEGAULT and J. GRUAND*
}

Station de Génétique quantitative et appliquée, I. N.R.A., C.N.R.Z., 78350 Jouy en Josas

* Station Expérimentale de Sélection porcine, I. N. R. A., 86480 Rowillé

Two systems of production of heavy carcasses were compared : In the "experimental group ", 28 Large White gilts were slaughtered two weeks after weaning of their first litter (at the average age and weight of $4 \mathrm{IO}$ days and $\mathrm{I}_{44} \mathrm{~kg}$, respectively), in the control group, 29 contemporary

Annales de Zootechnie. - 1975 . 
unmated gilts were slaughtered at the average age and weight of 244 days and $137 \mathrm{~kg}$.

I)ressing out percentage was significantly lower in primiparous gilts than in control gilts (74.7 vs 77.4 p. roo). On the other hand, carcasses from the experimental group were significantly leaner than those from the control group: In fact, average values for lean cuts (in p. Ioo) (loin and ham) fat cuts (in p. Ioo) (backfat and leaf fat) and back fat thickness were 54.I p. IOo; I6.8 p. Ioo and $38.9 \mathrm{~mm}$ respectively in the former $v s 49.7 \mathrm{p}$. IOo; $22.8 \mathrm{p}$. 100 and $48.0 \mathrm{~mm}$ in the latter. The shoulder was the heaviest in the first group while the belly was the heaviest in the control group. Except for color, other estimates of meat quality (moisture and acidity) gave the lowest values in the experimental group. The total superiority of the carcasses from primiparous gilts as compared to the controls ranged between 30 to 40 Frs.

The average cost of piglets weaned by experimental gilts $(7,7$ per litter) was about ioo Frs. It could have been reduced to 60 lits if the age at first mating had not exceeded 210 days and if early weaning had been practised. However, combined production of heavy carcasses and piglets can be advised in very specific and limited market conditions : moreover, any extension of this technique needs an accurate study of its genetic (selection pressure) and demographic (replacement rate of females) incidences.

\title{
Zootechnie performances and eareass traits in pigs fed with barley and slaughtered between 90 and $120 \mathrm{~kg}$ live weight
}

\author{
J. P. BOUARD and M. LELILLET \\ Institut technique des Cévéales et des Fourrages, \\ 8. Avenue du Président Wilson, \\ 75116 Paris
}

In our experimental conditions, variation in the slaughter weight of the animals between 90 and $120 \mathrm{~kg}$ connected with liberal feed allowance gave the following results :

- similar growth performances;

- higher feed conversion ratios ( $\mathrm{FCR}$ ) in the heaviest groups at slaughter.

- $\mathrm{FCR}=\mathrm{I}$ oo in group $\mathrm{I}$

- FCR $=104$ in groups 2 and 3

- $\mathrm{FCR}=\mathrm{IO} 7$ in group 4 (significant difference as compared to group I) ;

- higher dressing percentages with increasing slaughter weights : highly significant difference between group I (74,9 p. Ioo) 2 and $3(76.7$ p. Ioo) and 4 (77.7 p. I0o);

- carcasses with increasing proportions of subcutaneous depot fats : highly significant difference, which does not, however, affect very much the commercial grading (grading scale of the E. E. C.).

From an economic point of view, the heaviest pigs provide the greatest advantages, irrespective of the price of the piglet. However, it would be advisable to interpret and use these results with caution on account of the number of animals involved (although large for a comparative study) and of the specific experimental conditions, in particular the choice of the feeding schedule.

This study will be pursued during the course of the year 1975 . 